\title{
Dearomatized Isoprenylated Acylphloroglucinol Derivatives with Potential Antitumor Activities from Hypericum henryi
}

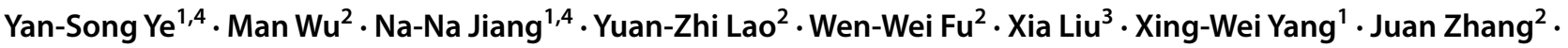 \\ Hong-Xi Xu' ${ }^{2}$ Gang Xu ${ }^{1}$
}

Received: 23 December 2019 / Accepted: 26 December 2019 / Published online: 4 February 2020

(c) The Author(s) 2020

\begin{abstract}
A series of dearomatized isoprenylated acylphloroglucinols derivatives, hyperhenols A-E (1-5), as well as seven known analogues (6-12), were characterized from Hypericum henryi. Their structures were determined by combination of NMR, ECD spectroscopy, and X-ray diffraction analysis. Compounds $\mathbf{1}$ and 6-8 were tested to exhibit potential antitumor properties, of which $\mathbf{6}$ and $\mathbf{7}$ inhibited cell growth through inducing apoptosis and cell cycle arrest. In addition, these compounds could induce autophagy and PINK1/Parkin-mediated mitophagy in cancer cell lines, as well as suppress lung cancer A549 cells metastasis in vitro.
\end{abstract}

Keywords Hypericum henryi · Dearomatized isoprenylated acylphloroglucinols (DIAPs) · Apoptosis · Cell cycle arrest

Yan-Song Ye, Man Wu and Na-Na Jiang have contributed equally to this work.

This paper is dedicated to Prof. Handong Sun on the occasion of his 80 th birthday.

Electronic supplementary material The online version of this article (https://doi.org/10.1007/s13659-019-00229-w) contains supplementary material, which is available to authorized users.

Hong-Xi Xu

xuhongxi88@gmail.com

$\triangle$ Gang Xu

xugang008@mail.kib.ac.cn

1 State Key Laboratory of Phytochemistry and Plant Resources in West China and Yunnan Key Laboratory of Natural Medicinal Chemistry, Kunming Institute of Botany, Chinese Academy of Sciences, Kunming 650201, China

2 School of Pharmacy, Shanghai University of Traditional Chinese Medicine, Shanghai 201203, China

3 Department of Pharmacy, Chongqing Traditional Chinese Medicine Hospital, Chongqing 400021, China

4 University of Chinese Academy of Sciences, Beijing 100049, China

\section{Introduction}

Natural phloroglucinol derivatives are widely distributed in Myrtaceae, Guttiferae, Euphorbiaceae, Aspidiaceae families as well as appeared in marine and microbial sources [1]. In which prenylated acylphloroglucinols are a special kind of hybrid natural products originated from a polyketide combined isoprenylation biosynthetic pathways, and were mainly reported from the plants of genus Hypericum and Garcinia in the family Guttiferae [2-4]. With their wide range of biological profiles and diverse molecular architectures exemplified by hyperforin [5], hypersubone B [6], hyperuralone A [7] and chinesins I/II [8], prenylated acylphloroglucinol derivatives have attracted great interest of chemists and pharmaceutists.

As a traditional folk medicine in China, Hypericum henryi has been used to treat hepatitis [9]. Previous investigations on this plant have reported structurally diverse polycyclic polyprenylated acylphloroglucinols (PPAPs) such as hyphenrones A-X [10-12]. As a part of systematic search on bioactive acylphloroglucinol derivatives, five new dearomatized isoprenylated acylphloroglucinols (DIAPs) derivatives, hyperhenols A-E (1-5) together with seven known analogues (6-12) were isolated from $H$. henryi (Fig. 1). In the bioactive study, compounds $\mathbf{1}$ and $\mathbf{6}-\mathbf{8}$ were found to exhibit promising cytotoxic activities against three human cancer cell lines in vitro. And the further studies indicated 


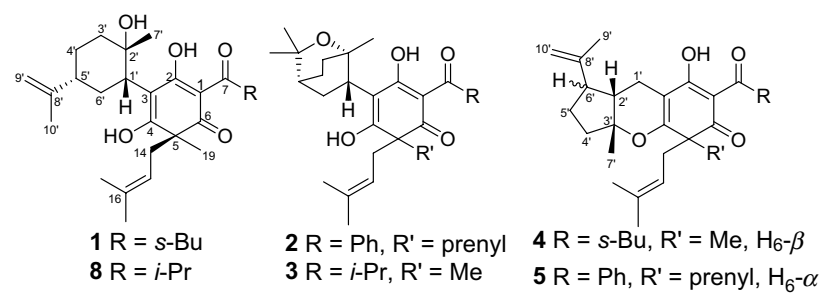

Fig. 1 Structures of compounds $\mathbf{1}-\mathbf{5}$

compounds $\mathbf{6}$ and 7 could trigger autophagy, PINK1/Parkinmediated mitophagy in cancer cell lines, and also suppress lung cancer A549 cells metastasis targeting Akt and cofilin signaling pathways. In addition, 6 and 7 also displayed significant anti-proliferation activities by inducing apoptosis and cell cycle arrest. Herein, the isolation, structure elucidation, and bioactivities evaluation of these compounds were reported.

\section{Results and Discussion}

The $\mathrm{MeOH}$ extract was subjected to repeated column chromatography to yield five new DIAPs derivatives (1-5) together with seven known analogues hyphenrone J (6) [13], hyphenrone K (7) [13], hyperhenone E (8) [12], hyperhenone A (9) [12], hyperhenone B (10) [12], hyperhenone C (11) [12], and hyperhenone D (12) [12].

Hyperhenol A (1) was isolated as yellow oil and assigned molecular formula of $\mathrm{C}_{27} \mathrm{H}_{40} \mathrm{O}_{5}$ with 8 degrees of unsaturation by HRESIMS $(\mathrm{m} / z \text { 443.2803 [M }-\mathrm{H}]^{-}$, calcd. $\left.\mathrm{C}_{27} \mathrm{H}_{39} \mathrm{O}_{5}, 443.2803\right)$. The IR spectrum displayed bands for hydroxy $\left(3417 \mathrm{~cm}^{-1}\right)$ and carbonyl groups $\left(1636 \mathrm{~cm}^{-1}\right)$. The ${ }^{13} \mathrm{C}$ NMR data along with DEPT experiments showed 27 carbon signals including seven methyls, six methylenes, four methines, and ten quaternary carbons (three oxygenated tertiary carbons and two carbonyls). Detailed analysis of the ${ }^{13} \mathrm{C}$ NMR spectroscopic data (Table 1) indicated the presence of an isoprenyl $\left(\delta_{\mathrm{C}} 40.3, \mathrm{C}-14 ; 120.5\right.$, C-15; 135.3 , C-16; 26.2, C-17; 18.2, C-18), a DIAPs core including an enolized 1,3-diketone group $\left(\delta_{\mathrm{C}} 199.0, \mathrm{C}-6 ; 107.4, \mathrm{C}-1\right.$; $191.0, \mathrm{C}-2)$, an enolic double bonds $\left(\delta_{\mathrm{C}} 111.1, \mathrm{C}-3 ; 179.4\right.$, C-4), a carbonyl $\left(\delta_{\mathrm{C}} 207.9, \mathrm{C}-7\right)$, and a quaternary carbon at $\delta_{\mathrm{C}} 54.7$ (C-5) [12, 13]. The location of the mentioned isoprenyl and the methyl $\left(\delta_{\mathrm{C}} 24.6, \mathrm{C}-19\right)$ at C-5 was evidenced by the HMBC correlations from $\mathrm{H}_{2}-14\left(\delta_{\mathrm{H}} 2.62,2.56\right)$ and $\operatorname{Me}-19\left(\delta_{\mathrm{H}} 1.32\right)$ to C-4 $\left(\delta_{\mathrm{C}} 179.4\right), \mathrm{C}-5\left(\delta_{\mathrm{C}} 54.7\right)$ and C-6 $\left(\delta_{\mathrm{C}}\right.$ 199.0) (Fig. 2). Besides the aforementioned DIAP moiety, the remaining 14 carbon signals can be attributed to a secbutyl group $\left(\delta_{\mathrm{C}} 43.4, \mathrm{C}-8 ; \delta_{\mathrm{C}} 17.1, \mathrm{C}-9 ; \delta_{\mathrm{C}} 27.7, \mathrm{C}-10 ; \delta_{\mathrm{C}}\right.$ 12.4, C-11) and another $\mathrm{C}_{10}$ unit.
Comparison of ${ }^{1} \mathrm{H}$ and ${ }^{13} \mathrm{C}$ NMR data indicated that the $\mathrm{C}_{10}$ unit of $\mathbf{1}$ shared a similar structure with the monoterpenoid moiety of callistrilone B [14], which was confirmed by the ${ }^{1} \mathrm{H}-{ }^{1} \mathrm{H}$ COSY correlations of $\mathrm{H}-3^{\prime} / \mathrm{H}-4^{\prime} / \mathrm{H}-5^{\prime} / \mathrm{H}-6^{\prime} / \mathrm{H}-1^{\prime}$, accompanied by HMBC correlations from Me-7' $\left(\delta_{\mathrm{H}} 1.18\right)$ to $\mathrm{C}-1^{\prime}\left(\delta_{\mathrm{C}} 42.7\right), \mathrm{C}-2^{\prime}\left(\delta_{\mathrm{C}} 73.3\right)$, and C-3' $\left(\delta_{\mathrm{C}} 41.0\right)$; from $\mathrm{Me}-10^{\prime}\left(\delta_{\mathrm{H}} 1.58\right)$ to $\mathrm{C}-8^{\prime}\left(\delta_{\mathrm{C}} 151.0\right), \mathrm{C}-5^{\prime}\left(\delta_{\mathrm{C}} 47.1\right)$, and C-9' $\left(\delta_{\mathrm{C}} 109.2\right)$; and from $\mathrm{H}_{2}-9^{\prime}\left(\delta_{\mathrm{H}} 4.71,4.67\right)$ to $\mathrm{C}-8^{\prime}\left(\delta_{\mathrm{C}} 151.0\right)$, C-10' $\left(\delta_{\mathrm{C}} 21.1\right)$, and C-5' $\left(\delta_{\mathrm{C}} 47.1\right)$. The linkage of DIAP core and monoterpenoid moiety between $\mathrm{C}-1^{\prime}$ and $\mathrm{C}-3$ was evidenced by $\mathrm{HMBC}$ correlations from $\mathrm{H}-1^{\prime}\left(\delta_{\mathrm{H}} 3.24\right)$ to

Table 1 The ${ }^{13} \mathrm{C}(150 \mathrm{MHz}) \mathrm{NMR}$ data of compounds $\mathbf{1}-\mathbf{5}$ ( $\delta$ in ppm)

\begin{tabular}{|c|c|c|c|c|c|}
\hline No & $1^{\mathrm{a}}$ & $2^{\mathrm{b}}$ & $3^{\mathrm{a}}$ & $4^{b}$ & $5^{\mathrm{b}}$ \\
\hline 1 & 107.4 & 107.5 & 106.3 & 106.5 & 108.2 \\
\hline 2 & 191.0 & 189.0 & 190.8 & 189.2 & 188.8 \\
\hline 3 & 111.1 & 112.4 & 112.1 & 103.3 & 103.3 \\
\hline 4 & 179.4 & 176.6 & 177.4 & 170.6 & 171.2 \\
\hline 5 & 54.7 & 57.6 & 54.6 & 52.4 & 57.0 \\
\hline 6 & 199.0 & 195.3 & 198.4 & 196.4 & 195.2 \\
\hline 7 & 207.9 & 195.5 & 208.5 & 206.8 & 196.3 \\
\hline 8 & 43.4 & 139.2 & 36.8 & 41.7 & 139.3 \\
\hline 9 & 17.1 & 127.6 & 19.2 & 16.4 & 127.8 \\
\hline 10 & 27.7 & 127.7 & 19.5 & 26.8 & 128.0 \\
\hline 11 & 12.4 & 130.6 & & 11.8 & 131.0 \\
\hline 12 & & 127.7 & & & 128.0 \\
\hline 13 & & 127.6 & & & 127.8 \\
\hline 14 & 40.3 & 38.5 & 38.8 & 38.0 & 37.3 \\
\hline 15 & 120.5 & 119.0 & 120.7 & 118.8 & 119.3 \\
\hline 16 & 135.3 & 133.7 & 135.2 & 134.2 & 134.0 \\
\hline 17 & 26.2 & 18.1 & 18.2 & 25.9 & 26.2 \\
\hline 18 & 18.2 & 25.9 & 26.1 & 18.1 & 26.2 \\
\hline 19 & 24.6 & 38.0 & 25.6 & 24.0 & 38.4 \\
\hline 20 & & 119.3 & & & 118.8 \\
\hline 21 & & 134.0 & & & 134.4 \\
\hline 22 & & 25.9 & & & 18.5 \\
\hline 23 & & 18.1 & & & 18.2 \\
\hline $1^{\prime}$ & 42.7 & 35.1 & 36.2 & 35.5 & 16.3 \\
\hline $2^{\prime}$ & 73.3 & 74.8 & 76.0 & 40.5 & 43.3 \\
\hline $3^{\prime}$ & 41.0 & 33.2 & 34.2 & 86.8 & 88.4 \\
\hline $4^{\prime}$ & 27.9 & 21.2 & 22.2 & 15.2 & 27.1 \\
\hline $5^{\prime}$ & 47.1 & 32.8 & 33.9 & 22.2 & 37.8 \\
\hline $6^{\prime}$ & 32.2 & 31.0 & 32.3 & 47.0 & 49.1 \\
\hline $7^{\prime}$ & 28.0 & 23.5 & 24.2 & 26.9 & 23.0 \\
\hline $8^{\prime}$ & 151.0 & 78.0 & 79.3 & 143.5 & 145.7 \\
\hline $9^{\prime}$ & 109.2 & 28.3 & 27.2 & 23.8 & 19.4 \\
\hline $10^{\prime}$ & 21.1 & 26.6 & 28.6 & 111.6 & 111.8 \\
\hline
\end{tabular}

${ }^{\mathrm{a}}$ Recorded in $\mathrm{CD}_{3} \mathrm{OD}$

${ }^{\mathrm{b}}$ Recorded in $\mathrm{CDCl}_{3}$ 


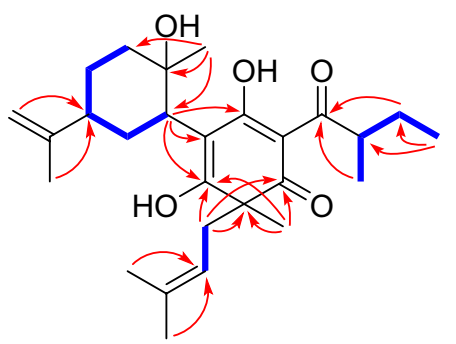

1

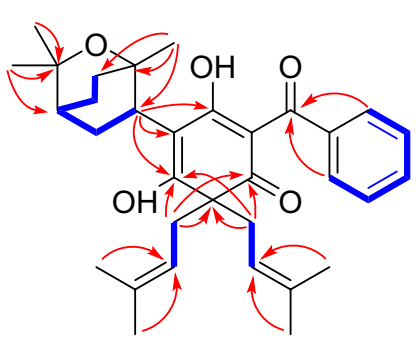

2

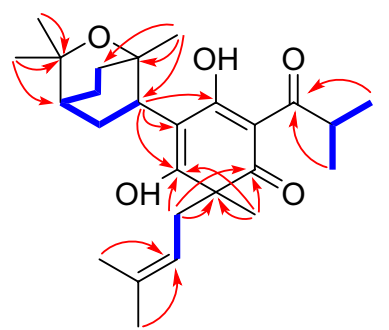

3

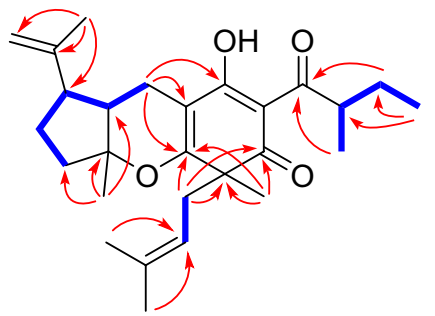

4

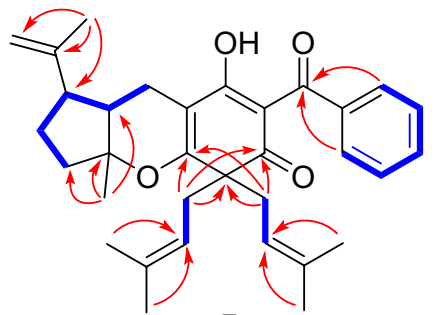

5

$-{ }^{1} \mathrm{H}-{ }^{1} \mathrm{H} \operatorname{COSY} \curvearrowright \mathrm{HMBC}$

Fig. 2 Key HMBC and ${ }^{1} \mathrm{H}-{ }^{1} \mathrm{H}$ COSY correlations of $\mathbf{1 - 5}$

C-2 $\left(\delta_{\mathrm{C}} 191.0\right), \mathrm{C}-3\left(\delta_{\mathrm{C}} 111.1\right)$, and C-4 $\left(\delta_{\mathrm{C}} 179.4\right)$ (Fig. 2$)$. Finally, the sec-butyl group only can be attached at C-1.

The relative configuration of monoterpenoid moiety was determined by detailed interpretation of the ROESY spectrum. The NOE correlations of $\mathrm{H}-5^{\prime} / \mathrm{H}-1^{\prime}$ and $\mathrm{H}-1^{\prime} / \mathrm{Me}-7^{\prime}$ indicated that $\mathrm{H}-5^{\prime}, \mathrm{H}-1^{\prime}$ and $\mathrm{Me}-7^{\prime}$ were on the same side. However, due to the rotation of carbon-carbon single bond (C-3/C-1') between DIAP core and monoterpenoid, determination of the configuration of $\mathrm{C}-5$ is still challenging. For instance, an analogue of $\mathbf{1}$ (hyperhenone E, $\mathbf{8}$ ), has also been reported with the configuration of C-5 undefined [12]. In this study, hyperhenone E, as well as its crystals, was fortunately obtained, which unambiguously determined absolute configurations of 8 as $5 S, 1^{\prime} R, 2^{\prime} R, 5^{\prime} S$ (Fig. 3). Furthermore, the absolute configurations of C-5, C-1', C-2' and C-5' in 1 were also determined to be the same with those of $\mathbf{8}$ via their well-matched ECD curves (Fig. 4).

Hyperhenol B (2) was obtained as yellow oil. A molecular formula of $\mathrm{C}_{33} \mathrm{H}_{42} \mathrm{O}_{5}$, was deduced by its ${ }^{13} \mathrm{C}$ NMR and HRESIMS $\left(\mathrm{m} / z\right.$ 519.3106 $[\mathrm{M}+\mathrm{H}]^{+}$, calcd. $\mathrm{C}_{33} \mathrm{H}_{43} \mathrm{O}_{5}$ 519.3105). The ${ }^{1} \mathrm{H}$ and ${ }^{13} \mathrm{C}$ NMR spectra of 2 and hyperhenone $\mathrm{F}$ are closely similar to each other [12]. Comparative analyses of their NMR data revealed that the isopropyl in hyperhenone $\mathrm{F}$ was replaced by a phenyl, which was supported by the $\mathrm{HMBC}$ correlations from $\mathrm{H}-9 / \mathrm{H}-13\left(\delta_{\mathrm{H}} 7.43\right)$ to C-7 $\left(\delta_{\mathrm{C}} 195.5\right)$ and C-8 $\left(\delta_{\mathrm{C}} 139.2\right)$ in 2 (Fig. 2$)$. Because of the rigidity of the bicyclic skeleton, cyclohexane moiety tended to form boat conformation. Hence, the ROESY correlations of $\mathrm{H}-1^{\prime} / \mathrm{H}-3^{\prime}\left(\delta_{\mathrm{H}} 1.96\right), \mathrm{H}-4^{\prime} / \mathrm{H}-6^{\prime}\left(\delta_{\mathrm{H}} 2.10\right)$, and

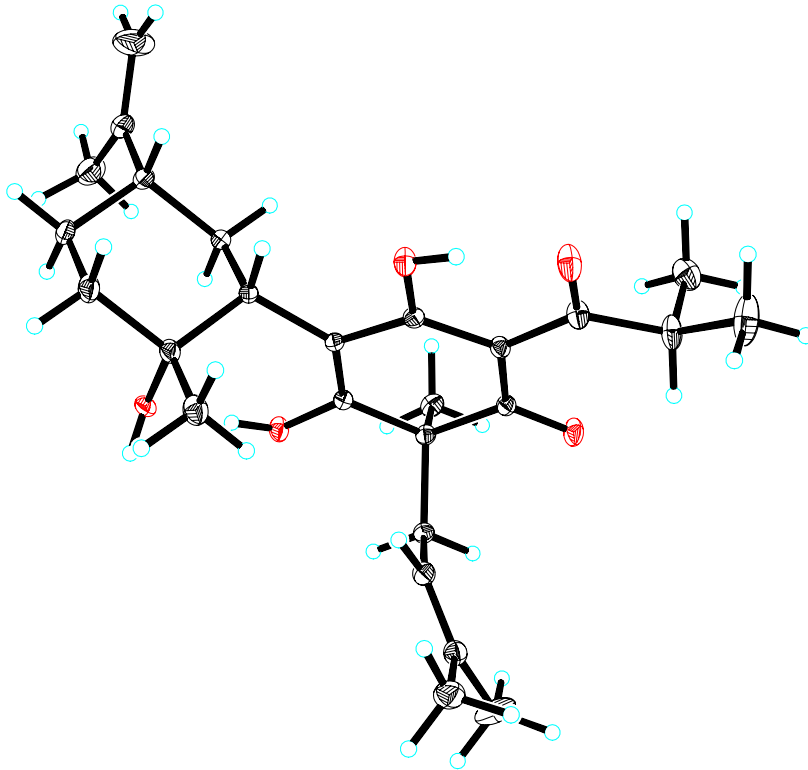

Fig. 3 X-ray structure of compound 8

H- $6{ }^{\prime} / \mathrm{H}-1^{\prime}$ showed the same orientations of $\mathrm{H}-1^{\prime}$ and Me- $7^{\prime}$ (Fig. 5).

Hyperhenol C (3) exhibited a molecular formula of $\mathrm{C}_{26} \mathrm{H}_{38} \mathrm{O}_{5}$, as assigned by HRESIMS $(\mathrm{m} / \mathrm{z} 429.2653$ $[\mathrm{M}-\mathrm{H}]^{-}$, calcd. $\mathrm{C}_{26} \mathrm{H}_{37} \mathrm{O}_{5}, 429.2646$ ). The NMR spectra of $\mathbf{3}$ showed a close resemblance to those of hyperhenone $\mathrm{F}$ except that the signals for the isoprenyl at C-5 in 


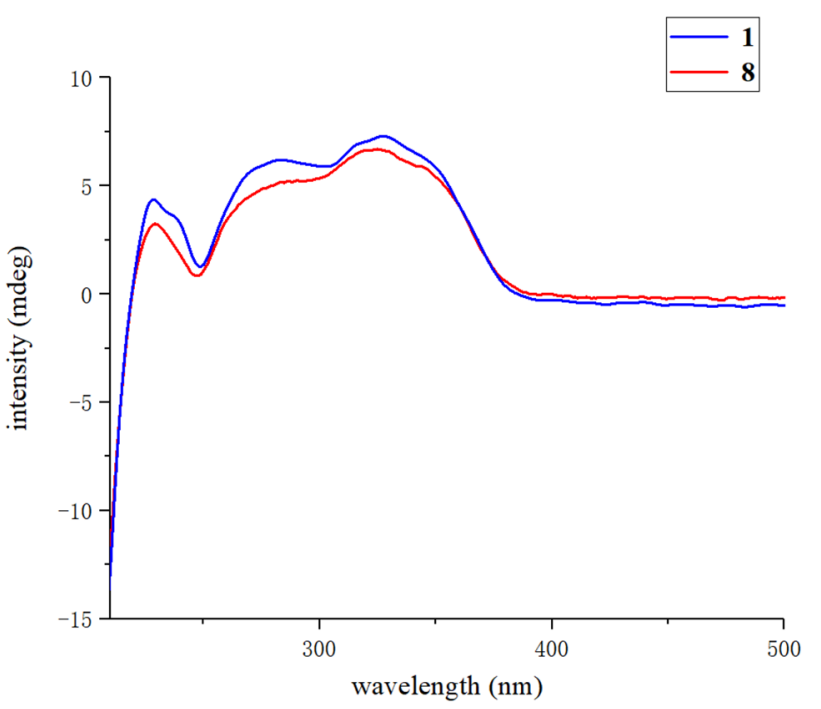

Fig. 4 Experimental ECD spectra of $\mathbf{1}$ and $\mathbf{8}$

hyperhenone $\mathrm{F}$ was replaced by a methyl in $\mathbf{3}$ [12], which can be further confirmed by the HMBC correlations from Me-19 $\left(\delta_{\mathrm{H}} 1.35\right)$ to C-5 $\left(\delta_{\mathrm{C}} 54.6\right), \mathrm{C}-4\left(\delta_{\mathrm{C}} 177.4\right), \mathrm{C}-6\left(\delta_{\mathrm{C}}\right.$ $198.4)$ and $\mathrm{C}-14\left(\delta_{\mathrm{C}} 38.8\right)$. The similar NOE correlations of $\mathrm{H}-1^{\prime} / \mathrm{H}-3^{\prime}\left(\delta_{\mathrm{H}} 1.70\right), \mathrm{H}-3^{\prime} / \mathrm{H}-4^{\prime}\left(\delta_{\mathrm{H}} 2.09\right), \mathrm{H}-4^{\prime} / \mathrm{H}-6^{\prime}\left(\delta_{\mathrm{H}} 1.61\right)$ and $\mathrm{H}-6^{\prime} / \mathrm{H}-1^{\prime}$ showed that relative configurations were the same as those of 2 (Fig. 5). In the absence of sufficient evidence, configuration of $\mathrm{C}-5$ could not be determined.

Hyperhenol D (4) was obtained as yellow oil. The molecular formula was established as $\mathrm{C}_{27} \mathrm{H}_{38} \mathrm{O}_{4}$ based on its HRESIMS data $\left(\mathrm{m} / z 427.2855[\mathrm{M}+\mathrm{H}]^{+}\right.$, calcd. $\mathrm{C}_{27} \mathrm{H}_{39} \mathrm{O}_{4}$ 427.2843), implying 9 indices of hydrogen deficiency. The characteristic information for a DIAPs core was clearly observed in the ${ }^{13} \mathrm{C}$ NMR spectra $\left(\delta_{\mathrm{C}} 106.5, \mathrm{C}-1 ; \delta_{\mathrm{C}} 189.2\right.$, $\mathrm{C}-2 ; \delta_{\mathrm{C}} 103.3, \mathrm{C}-3 ; \delta_{\mathrm{C}} 170.6 \mathrm{C}-4 ; \delta_{\mathrm{C}} 52.4 \mathrm{C}-5 ; \delta_{\mathrm{C}} 196.4$ C-6). A comparison of the 1D NMR data of 4 with those of chinesin I suggested that they shared closely similar plane structures [8]. The molecular formulas $\left(\mathrm{C}_{27} \mathrm{H}_{40} \mathrm{O}_{4}\right.$ for chinesin I; $\mathrm{C}_{27} \mathrm{H}_{38} \mathrm{O}_{4}$ for $\mathbf{4}$ ) revealed that $\mathbf{4}$ possessed one more degree of unsaturation [8], which could derived by the loss of $\mathrm{H}_{2} \mathrm{O}$ between hydroxyls of monoterpenoid and DIAPs core of chinesin I to afford 4 . The ether linkage of C-4 and $\mathrm{C}-3^{\prime}$ was evidenced by indices of hydrogen deficiency, the downfield chemical shift of C-3' $\left(\delta_{\mathrm{C}} 86.8\right)$ and the ROESY correlation of Me-7'/Me-17. The relative configurations of C-2', C-3', and C-6' were elucidated by key ROESY correlations of Me-7'/H-2', Me-7'/H-6', and H-2'/H-6'. Unfortunately, the configuration of $\mathrm{C}-5$ also could not be determined since the absence of sufficient evidence.

Hyperhenol E (5) was obtained as yellow oil, and its HRESIMS spectrum $\left(\mathrm{m} / \mathrm{z} 501.3008[\mathrm{M}+\mathrm{H}]^{+}\right.$, calcd. $\mathrm{C}_{33} \mathrm{H}_{41} \mathrm{O}_{4}$ 501.2999) showed a molecular formula of $\mathrm{C}_{33} \mathrm{H}_{40} \mathrm{O}_{4}$. The ${ }^{1} \mathrm{H}$ NMR data of 5 (Table 2) exhibited a monosubstituted benzene $\left(\delta_{\mathrm{H}} \mathrm{H} 7.30,3 \mathrm{H} ; 7.38,2 \mathrm{H}\right)$, two isoprenyl $\left(\delta_{\mathrm{H}} 4.75, \mathrm{t}, J=7.2 \mathrm{~Hz} ; \delta_{\mathrm{H}} 4.81, \mathrm{t}, J=7.2 \mathrm{~Hz}\right)$. The NMR spectra of $\mathbf{5}$ showed a close resemblance to those of 4 except for the replacements of the sec-butyl group at C-7 and the methyl at C-5 in $\mathbf{4}$ by a phenyl and an isoprenyl in 5, respectively. This conclusion was verified via the ${ }^{1} \mathrm{H}-{ }^{1} \mathrm{H}$ COSY cross peak of $\mathrm{H}_{2}-19 / \mathrm{H}-20$ combined with the HMBC correlations of $\mathrm{H}_{2}-19\left(\delta_{\mathrm{H}} 2.57\right.$ and 2.38$)$ with $\mathrm{C}-4\left(\delta_{\mathrm{C}} 171.2\right) /$ C-5 $\left(\delta_{\mathrm{C}} 57.0\right) / \mathrm{C}-6$ and $\mathrm{H}-9\left(\delta_{\mathrm{H}} 7.30\right) / \mathrm{H}-13\left(\delta_{\mathrm{H}} 7.30\right)$ with C-7 $\left(\delta_{\mathrm{C}} 195.2\right) / \mathrm{C}-8\left(\delta_{\mathrm{C}} 108.2\right)$. In the ROESY spectrum, the obvious NOE correlation between Me-7' and H-2' can also be found as that in 4, but the diagnostic signals of $\mathrm{H}-2^{\prime} / \mathrm{H}-6^{\prime}$ and $\mathrm{Me}-7^{\prime} / \mathrm{H}-6^{\prime}$ in 4 were replaced by the $\mathrm{H}-2^{\prime} / \mathrm{Me}-9^{\prime}$ and $\mathrm{H}-2^{\prime} / \mathrm{H}-10\left(\delta_{\mathrm{H}} 4.62\right)$, which indicated that the orientation of H-6' was different with that of Me-7'/H-2'.

In the searching for their anticancer properties, compounds $\mathbf{1}$ and 6-8 were found to effectively inhibit cell growth in HeLa, A549, and MDAMB-231 cell lines (Table 3). Of which 6 and 7 could significant inhibit cancer cells growth with the $\mathrm{IC}_{50}$ up to 0.07 and $0.09 \mu \mathrm{M}$, respectively. Both the two compounds could also obviously increase mitochondrial fission and further activated the caspase-3, caspase-9, and increased PARP cleavage in HeLa cells (Fig. 6a, c). Treatment with $\mathbf{6}$ and $\mathbf{7}$ also increased the percentage of cells in G0/G1 phase and decreased in G2/M phase (Fig. 6b). Moreover, western blot results indicated that these two compounds efficiently suppressed the expression of cyclin D1 and Cdk 6 in HeLa cells, suggesting 6 and 7 induced cell cycle arrest. (Fig. 6c). Taken together, these
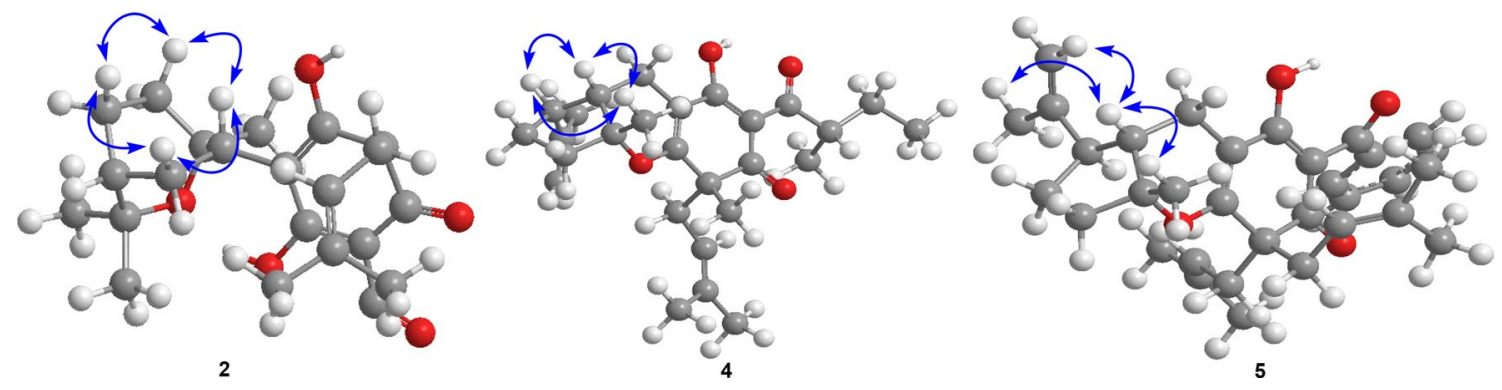

Fig. 5 Key ROESY correlations of 2, 4 and 5 
Table 2 The ${ }^{1} \mathrm{H}(600 \mathrm{MHz}) \mathrm{NMR}$ data of compounds $\mathbf{1}-\mathbf{5}(\delta$ in ppm and $J$ in $\mathrm{Hz})$

\begin{tabular}{|c|c|c|c|c|c|}
\hline No & $\mathbf{1}^{\mathrm{a}}$ & $2^{\mathrm{b}}$ & $3^{\mathrm{a}}$ & $4^{b}$ & $5^{\mathrm{b}}$ \\
\hline 8 & $3.87, \mathrm{~m}$ & & 3.98, sept (6.9) & $3.86, \mathrm{~m}$ & \\
\hline 9 & $1.09, \mathrm{~d}(6.6)$ & 7.43 , overlap & $1.11, \mathrm{~d}(6.9)$ & $1.10, \mathrm{~d}(6.9)$ & 7.30, overlap \\
\hline 10 & $\begin{array}{l}1.81 \text {, overlap } \\
1.62 \text {, overlap }\end{array}$ & 7.35 , overlap & $1.10, \mathrm{~d}(6.9)$ & $\begin{array}{l}1.68, \text { overlap } \\
1.34, \mathrm{~m}\end{array}$ & 7.38 , overlap \\
\hline 11 & $0.89, \mathrm{~m}$ & 7.43, overlap & & $0.89, \mathrm{~m}$ & 7.38 , overlap \\
\hline 12 & & 7.35 , overlap & & & 7.38, overlap \\
\hline 13 & & 7.43 , overlap & & & 7.30, overlap \\
\hline 14 & $\begin{array}{l}2.62, \mathrm{~m} \\
2.56, \mathrm{~m}\end{array}$ & 2.61 , overlap & $2.63, \mathrm{~d}(7.8)$ & $\begin{array}{l}2.62, \mathrm{~m} \\
2.41, \mathrm{~m}\end{array}$ & $\begin{array}{l}2.57, \mathrm{~m} \\
2.47, \mathrm{~m}\end{array}$ \\
\hline 15 & 4.83 , overlap & 4.88 , overlap & $4.78, \mathrm{t}(7.2)$ & $4.72, \mathrm{t}(7.2)$ & $4.75, \mathrm{t}(7.2)$ \\
\hline 17 & $1.54, \mathrm{~s}$ & $1.58, \mathrm{~s}$ & $1.58, \mathrm{~s}$ & $1.54, \mathrm{~s}$ & $1.58, \mathrm{~s}$ \\
\hline 18 & $1.58, \mathrm{~s}$ & $1.47 \mathrm{~s}$ & $1.51, \mathrm{~s}$ & $1.54, \mathrm{~s}$ & $1.55, \mathrm{~s}$ \\
\hline 19 & $1.32, \mathrm{~s}$ & 2.61 , overlap & $1.35, \mathrm{~s}$ & $1.28, \mathrm{~s}$ & $\begin{array}{l}2.57, \mathrm{~m} \\
2.38, \mathrm{~m}\end{array}$ \\
\hline 20 & & 4.88 , overlap & & & $4.81, \mathrm{t},(7.2)$ \\
\hline 22 & & $1.37 \mathrm{~s}$ & & & $1.53, \mathrm{~s}$ \\
\hline 23 & & 2.61 , overlap & & & $1.53, \mathrm{~s}$ \\
\hline $1^{\prime}$ & $3.24, \mathrm{~m}$ & $3.35, \mathrm{~m}$ & $3.39, \mathrm{~m}$ & $1.81, \mathrm{~m}$ & $2.47, \mathrm{~d}(8.2)$ \\
\hline $2^{\prime}$ & & & & 1.93 , overlap & $2.24, \mathrm{~d}(8.2)$ \\
\hline $3^{\prime}$ & $\begin{array}{l}1.81 \text {, overlap } \\
1.62 \text {, overlap }\end{array}$ & $\begin{array}{l}1.96, \mathrm{~m} \\
1.68, \text { overlap }\end{array}$ & $\begin{array}{l}2.00, \mathrm{~m} \\
1.70, \mathrm{~m}\end{array}$ & & $1.92, \mathrm{dd}(12.0,6.5)$ \\
\hline $4^{\prime}$ & $\begin{array}{l}\text { 1.81, overlap } \\
1.37, \mathrm{~m}\end{array}$ & $\begin{array}{l}1.96, \mathrm{~m} \\
1.68, \text { overlap }\end{array}$ & $\begin{array}{l}2.09, \mathrm{~m} \\
1.73, \mathrm{~m}\end{array}$ & $\begin{array}{l}2.31, \mathrm{~m} \\
1.68, \text { overlap }\end{array}$ & 1.77 , overlap \\
\hline $5^{\prime}$ & $2.09, \mathrm{~m}$ & $1.47, \mathrm{~m}$ & 1.61, overlap & $\begin{array}{l}1.93, \text { overlap } \\
1.68, \text { overlap }\end{array}$ & $\begin{array}{l}2.03, \text { ms } \\
1.77, \text { overlap }\end{array}$ \\
\hline $6^{\prime}$ & $\begin{array}{l}1.92, \mathrm{~m} \\
1.30, \text { overlap }\end{array}$ & $\begin{array}{l}2.10, \mathrm{~m} \\
1.59, \mathrm{~m}\end{array}$ & $\begin{array}{l}2.12, \mathrm{~m} \\
1.61, \text { overlap }\end{array}$ & $2.79, \mathrm{~m}$ & $2.24, \mathrm{~m}$ \\
\hline $\begin{array}{l}7^{\prime} \\
8^{\prime}\end{array}$ & $1.18, \mathrm{~s}$ & $1.10, \mathrm{~s}$ & $0.98, \mathrm{~s}$ & $1.45, \mathrm{~s}$ & $1.26, \mathrm{~s}$ \\
\hline $9^{\prime}$ & $\begin{array}{l}4.71, \mathrm{~s} \\
4.67, \mathrm{~s}\end{array}$ & $1.37, \mathrm{~s}$ & $1.40, \mathrm{~s}$ & $1.76, \mathrm{~s}$ & $1.62, \mathrm{~s}$ \\
\hline $10^{\prime}$ & $1.58, \mathrm{~s}$ & $1.30, \mathrm{~s}$ & $1.33, \mathrm{~s}$ & $\begin{array}{l}4.93, \mathrm{~s} \\
4.72, \mathrm{~s}\end{array}$ & $\begin{array}{l}4.72, \mathrm{~s} \\
4.62, \mathrm{~s}\end{array}$ \\
\hline
\end{tabular}

${ }^{\text {a }}$ Recorded in $\mathrm{CD}_{3} \mathrm{OD}$

${ }^{\mathrm{b}}$ Recorded in $\mathrm{CDCl}_{3}$

Table 3 Cytotoxicity of the isolates on three cancer cell lines with $\mathrm{IC}_{50}$ values $(\mu \mathrm{M})$

\begin{tabular}{lllc}
\hline Compound $^{\mathrm{a}}$ & HeLa & A549 & MDA-MB-231 \\
\hline 1 & $0.88 \pm 0.042$ & $3.53 \pm 0.074$ & $4.18 \pm 0.43$ \\
6 & $0.07 \pm 0.04$ & $1.85 \pm 0.18$ & $1.37 \pm 0.13$ \\
7 & $0.09 \pm 0.099$ & $3.10 \pm 0.11$ & $1.11 \pm 0.06$ \\
8 & $0.89 \pm 0.41$ & $4.93 \pm 1.08$ & $22.16 \pm 0.83$ \\
Etoposide $^{\mathrm{b}}$ & $9.46 \pm 0.64$ & $2.98 \pm 1.08$ & $31.31 \pm 0.76$ \\
\hline
\end{tabular}

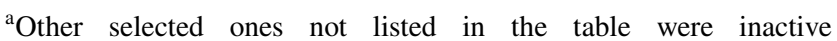
$\left(\mathrm{IC}_{50}>40 \mu \mathrm{M}\right.$ ) for cell lines

${ }^{\mathrm{b}}$ Etoposide was used as positive controls results demonstrated that these compounds inhibited cell growth through inducing apoptosis and cell cycle arrest.

Autophagy is widely implicated in human diseases, offering a potential target for drug discovery [15]. Then, the effects of 6 and 7 on autophagy were assessed. GFP-LC3 puncta were significantly increased upon these compounds treatment (Fig. 7a). Western blot analysis showed that 6 and 7 inhibited autophagy, as assessed by the increased expression of LC3 II and P62 (Fig. 7b). Similar to CCCP (mitophagy inducer) treatment, 6 and $\mathbf{7}$ also increased the YFP-Parkin puncta formation (Fig. 7c). These data suggested that the compounds could induce PINK1/Parkinmediated mitophagy. In addition, the antimetastasis effects 

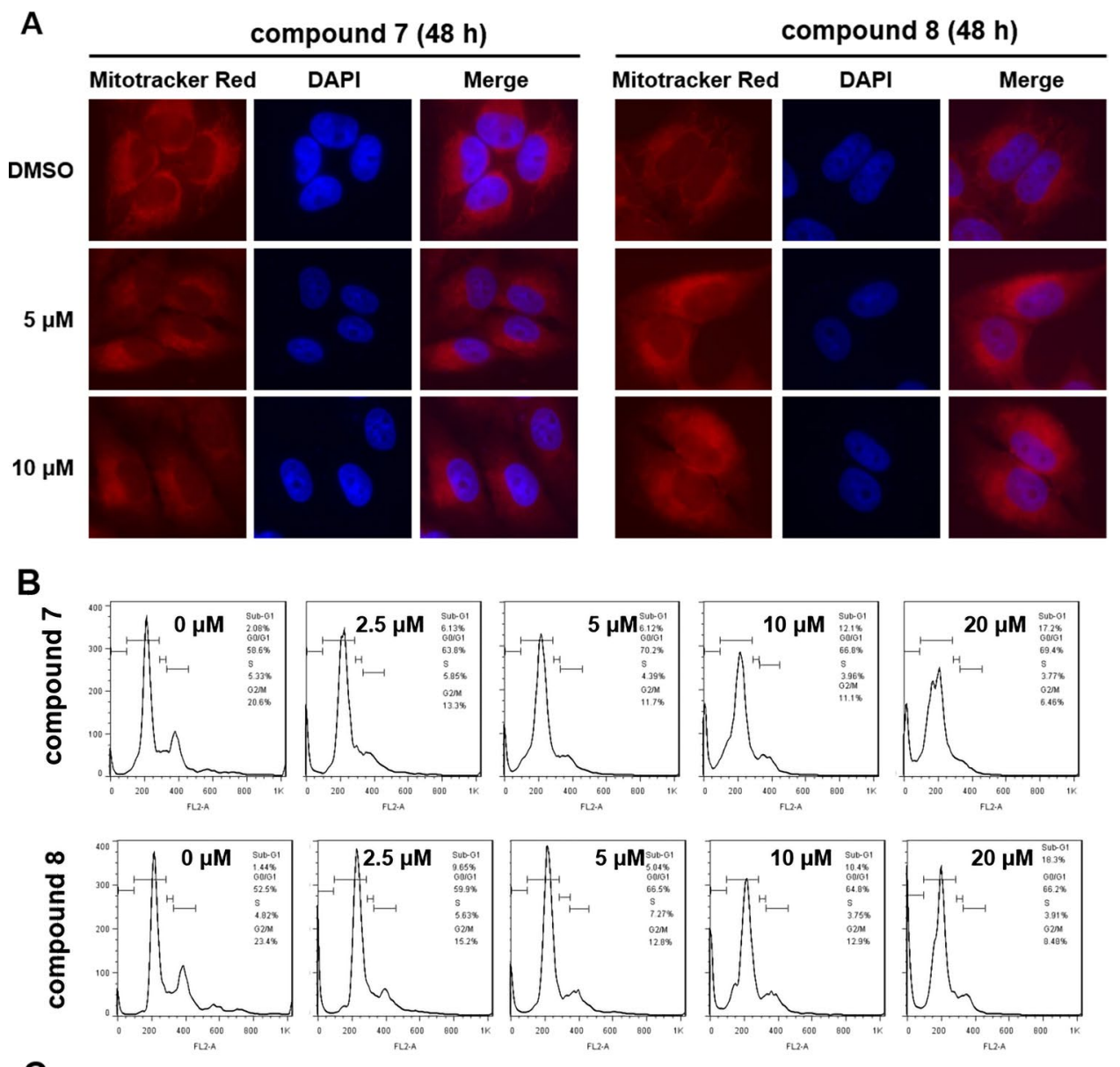

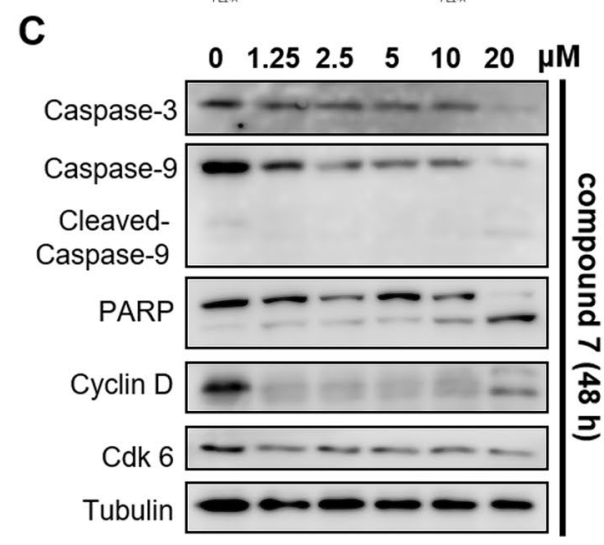

Fig. 6 Effects of compounds on apoptosis and cell cycle. a HeLa cells were stained with MitoTracker red $(100 \mathrm{nM})$ and analyzed by fluorescence microscope. Scale bars: $10 \mu \mathrm{M}$. b Cell cycle analysis in

of these compounds were also studied. As shown in Fig. 8, wound healing and migration assay suggested $\mathbf{6}$ and 7 could efficiently suppress cell metastasis consistent with sorafenib (SFB) treated, which also decreased the expression of vimentin, p-AKT and cofilin (Fig. 8). Together, these results indicated that these isolates could suppress lung

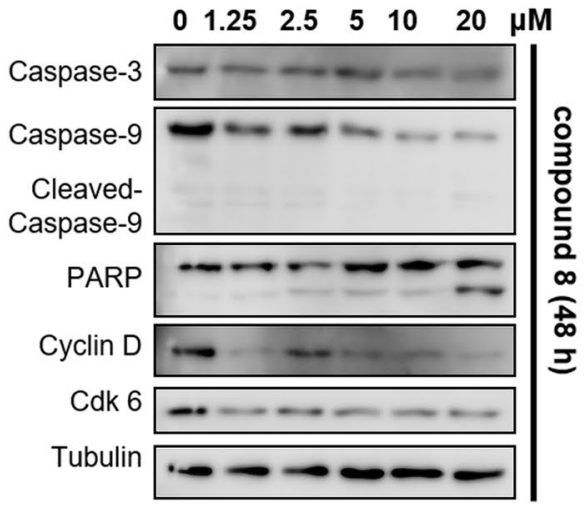

Hela cells after 48 h. c Apoptotic and cell cycle related proteins were analyzed by western blot

cancer A549 cells metastasis in vitro and may affect tumor metastasis targeted by Akt and cofilin signaling pathways.

In summary, five new and seven known DIAPs derivatives were isolated from $H$. henryi. Structurally, these compounds were characterized by a dearomatized isoprenylated acylphloroglucinol core combined a functionalized cyclohexane or cyclopentane skeleton. It is worthy to note 
A

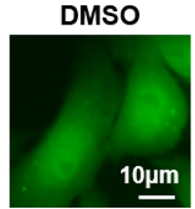

B
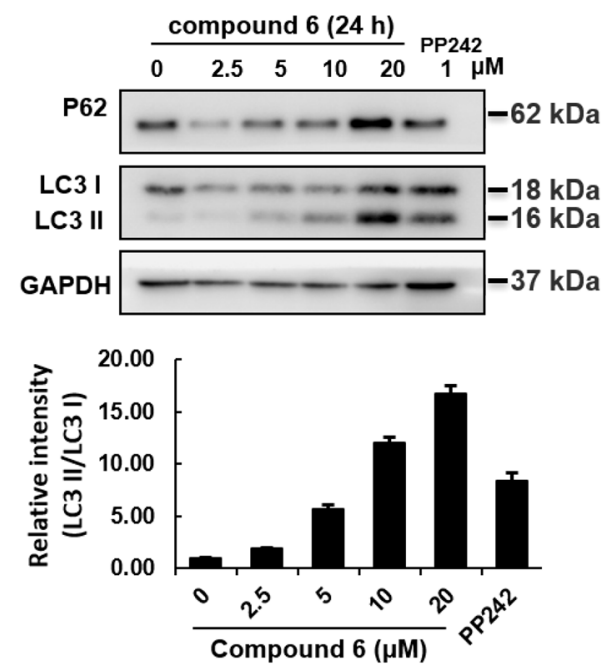

C
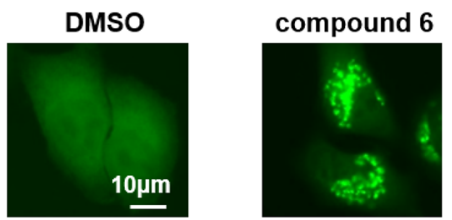

D

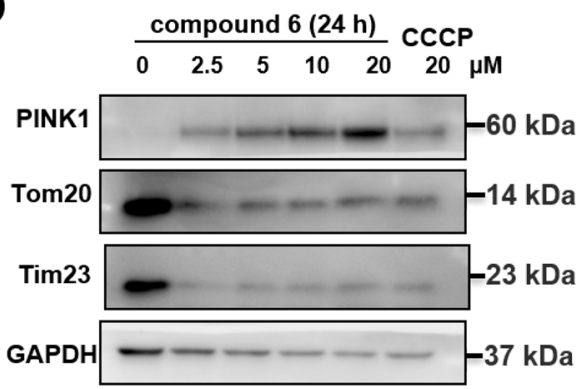

Fig. 7 Effects of compounds on autophagy/mitophagy. a Induction of autophagy in GFP-LC3 HeLa cells after $24 \mathrm{~h}$ and GFP-LC3 puncta were observed with a fluorescent microscope. Scale bars: $10 \mu \mathrm{M}$. b Autophagy related proteins were analyzed by western blot. c Induc-

that several isolates exhibited significant cytotoxic activities in vitro. In addition, they also possess inducing autophagy, mitophagy, and anti-metastasis activities, which provided sufficient information on the potential application of these compounds on future drug development. Therefore, the finding of these DIAPs derivatives with potential antitumor properties may provide a new clue for the discovery of antitumor lead compounds, which should attract great interest from pharmacological and total synthetic communities.
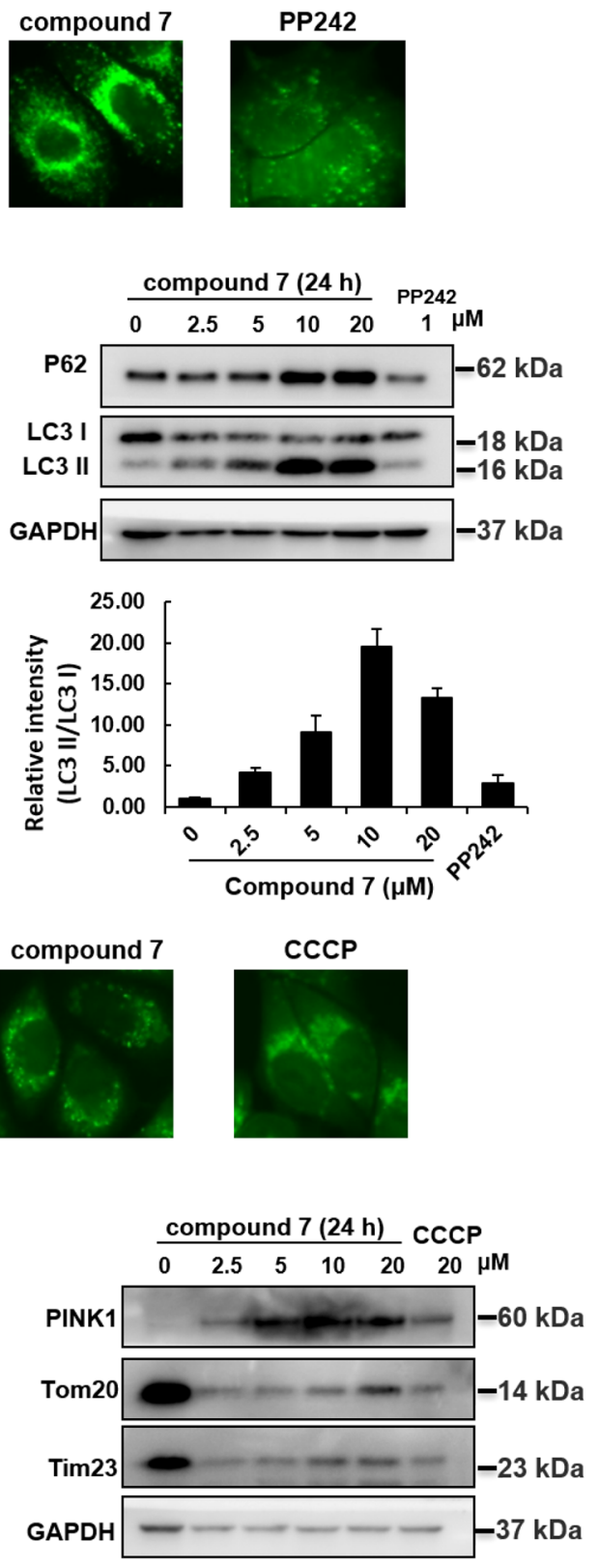

tion of mitophagy in YFP-Parkin HeLa cells after $4 \mathrm{~h}$ and YFP-Parkin puncta were observed with a fluorescent microscope. Scale bars: $10 \mu \mathrm{M}$. d Mitophagy related proteins were analyzed by western blot

\section{Experimental}

\subsection{General Experimental Procedures}

Optical rotations were measured on a Jasco P-1020 polarimeter. UV spectra were detected on a Shmadzu UV-2401PC spectrometer. IR spectra were determined on a Bruker FT-IR Tensor-27 infrared spectrophotometer with $\mathrm{KBr}$ disks. All 1D and 2D NMR spectra were recorded on Bruker DRX-600 spectrometers using TMS as an internal standard. Unless 
A
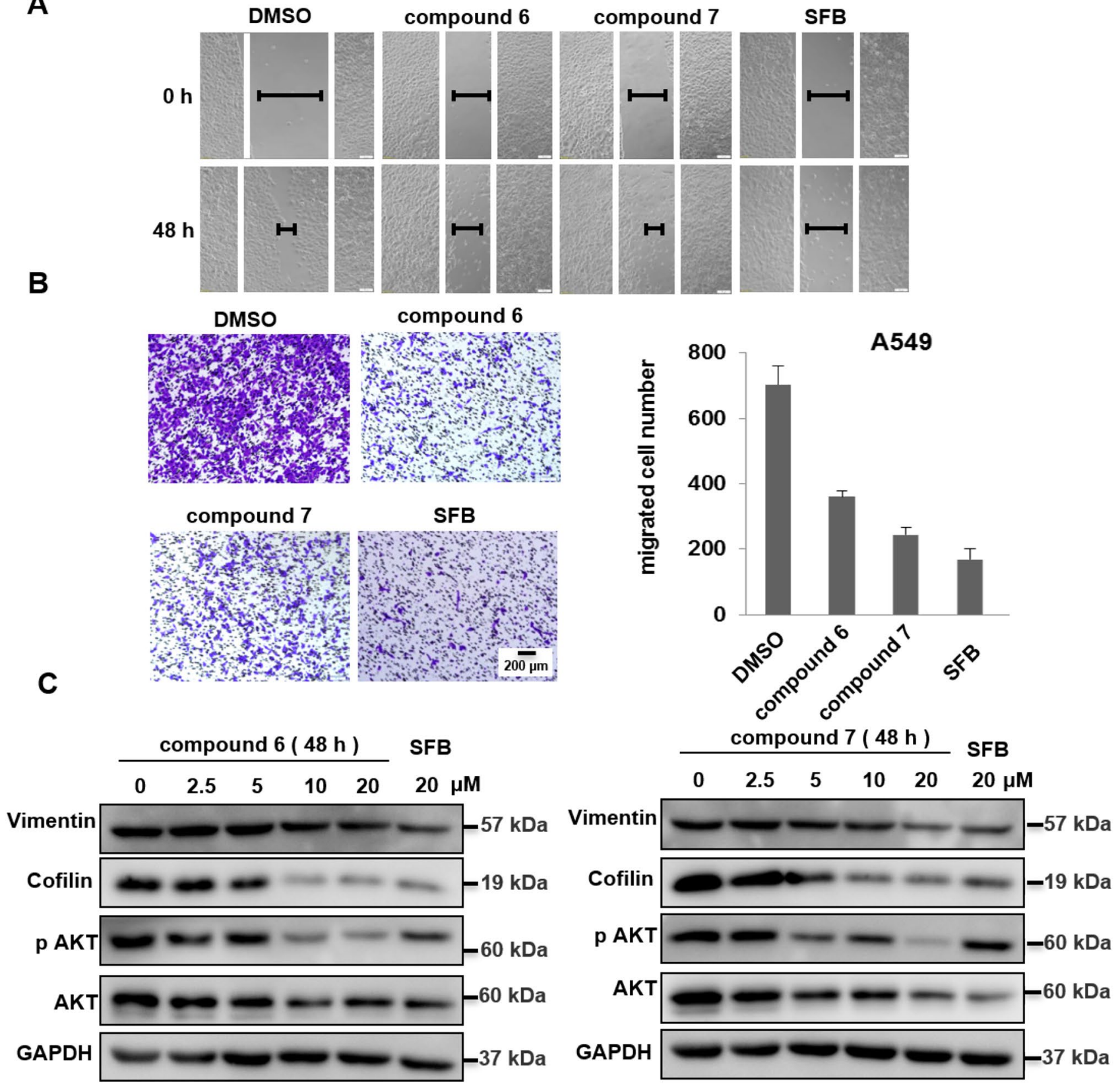

Fig. 8 a Wound healing assay. A549 cells were treated with compounds 6 and 7 and positive control Sorafenib $(20 \mu \mathrm{M})$ and monitored with an inverted microscope. $\mathbf{b}$ Cell migration was measured by transwell assays. The summary data for transwell migration assay was

otherwise specified, chemical shifts $(\delta)$ were expressed in ppm with reference to the solvent signals. ESIMS and HRESIMS analysis were carried out on Waters Xevo TQS and Aglient G6230 TOF mass spectrometers, respectively. Semi-preparative HPLC was performed on an Aglient 1100 HPLC with a ZORBAX SB-C18 $(9.4 \times 250 \mathrm{~mm})$ column and a Waters 2695 HPLC with a CHIRALCEL OJ-RH column $[4.6 \times 150 \mathrm{~mm}$ cellulose tris-(4-methylbenzoate) coated presented as the means \pm S.D. Scale bars: $10 \mu \mathrm{M}$. c A549 cells were treated with compounds 4-7 for $24 \mathrm{~h}$ and then analyzed by western blot

on $5 \mu \mathrm{M}$ silica-gel]. Silica gel (100-200, 200-300 mesh, Qingdao Marine Chemical Co., Ltd., People's Republic of China), and MCI gel (75-150 $\mu \mathrm{M}$, Mitsubishi Chemical Corporation, Tokyo, Japan) were used for column chromatography. Fractions were monitored by TLC (GF 254, Qingdao Marine Chemical Co., Ltd.), and spots were visualized by heating silica gel plates sprayed with $10 \% \mathrm{H}_{2} \mathrm{SO}_{4}$ in EtOH. 


\subsection{Plant Material}

The plants of Hypericum henryi were collected in Dongchuan prefecture (Yunnan Province, People's Republic of China) in September 2018. The plant was identified by ZHANG Yong-Zeng. A voucher specimen (No. 2018H01) was deposited in Kunming Institute of Botany.

\subsection{Extraction and Isolation}

The sample $(20.0 \mathrm{~kg})$ was extracted with $\mathrm{MeOH}$ at room temperature and filtered, and the solvent was evaporated in vacuo. The crude extract was subjected to silica gel column chromatography eluted with $\mathrm{CHCl}_{3}$ to afford a fraction $(695.2 \mathrm{~g})$. This fraction was separated over a MCI-gel column (MeOH- $\mathrm{H}_{2} \mathrm{O}$ from 7:3 to 10:0) to produce five fractions (Fr. A-E). Fr. A (262.3 g) was chromatographed on a silica gel column, eluted with petroleum ether-acetone (100:1 to 0:1), to yield five fractions (Fr. A1-A5). Fr. A2 (37.7 g) was separated over a RP-18 silica column $\left(\mathrm{MeOH}-\mathrm{H}_{2} \mathrm{O}\right.$ from 85:15 to 100:0) and obtained eleven fractions (Fr. A2-1-A2-11). Fr. A2-5 was purified by preparative TLC and semipreparative HPLC to afford $\mathbf{9}(12.3 \mathrm{mg}), \mathbf{1 0}(11.5 \mathrm{mg})$ and $2(10.8 \mathrm{mg})$. Fr. B (100 g) was chromatographed on a silica gel column, eluted with petroleum ether-ethyl acetate (50:1 to $0: 1$ ) to yield ten fractions (Fr. B1-B10). Fr. B3 $(11.0 \mathrm{~g})$ was purified by chromatograph on a silica gel column and preparative HPLC $\left(\mathrm{MeOH}-\mathrm{H}_{2} \mathrm{O}, 95: 5\right)$ to afford $\mathbf{1 1}$ $(25.9 \mathrm{mg})$ and $12(4.7 \mathrm{mg})$. Fr. B4 (755.9 mg) and B6 (1.2 g) were further purified by prearative $\mathrm{HPLC}\left(\mathrm{MeOH}-\mathrm{H}_{2} \mathrm{O}\right.$, 90:10) to afford $\mathbf{1}(15.1 \mathrm{mg}), \mathbf{3}(13.3 \mathrm{mg}), \mathbf{6}(26.5 \mathrm{mg})$ and 7 $(12.0 \mathrm{mg})$. Fr. B2 $(18.0 \mathrm{~g})$ was separated over a RP-18 silica column ( $\mathrm{MeOH}-\mathrm{H}_{2} \mathrm{O}$ from 85:15 to 100:0), and obtained ten fractions (Fr. B2-1-B2-10) Compounds 4 (7.8 mg), 5 $(1.3 \mathrm{mg})$ and $\mathbf{8}(3.2 \mathrm{mg})$ were obtained from Fr. B2-2 by preparative HPLC and semipreparative HPLC.

\subsubsection{Hyperhenol (1)}

Yellow oil; $[\alpha]+250.8(c 0.35, \mathrm{MeOH}) ; \mathrm{UV}(\mathrm{MeOH}) \lambda_{\max }$ $(\log \varepsilon) 202$ (4.14), 225 (4.10), 346 (4.02) nm; IR (KBr) $\nu_{\max }$ 3417, 2968, 2932, 1636, 1520, 1460, 1337, 1304, $1233 \mathrm{~cm}^{-1}$; ${ }^{1} \mathrm{H}$ and ${ }^{13} \mathrm{C}$ NMR data, see Tables 1 and 2; ESIMS $\mathrm{m} / \mathrm{z} 443$ $[\mathrm{M}-\mathrm{H}]^{-}$; HRESIMS $\mathrm{m} / z$ 443.2803 $[\mathrm{M}-\mathrm{H}]^{-}$(calcd for $\mathrm{C}_{27} \mathrm{H}_{39} \mathrm{O}_{5}, 433.2803$ ).

\subsubsection{Hyperhenol (2)}

Yellow oil; $[\alpha]+53.8(c 0.24, \mathrm{MeOH}) ; \mathrm{UV}(\mathrm{MeOH}) \lambda_{\max }$ (log $\varepsilon) 203$ (4.40), 227 (4.20), 343 (3.90) nm; IR (KBr) $\nu_{\max }$ $3427,2969,2927,1623,1505,1448,1257,1202 \mathrm{~cm}^{-1}$; ${ }^{1} \mathrm{H}$ and ${ }^{13} \mathrm{C}$ NMR data, see Tables 1 and 2; ESIMS $\mathrm{m} / \mathrm{z} 519$ $[\mathrm{M}+\mathrm{H}]^{+}$; HRESIMS $\mathrm{m} / z[\mathrm{M}+\mathrm{H}]^{+} ; 519.3106$ (calcd for $\mathrm{C}_{33} \mathrm{H}_{43} \mathrm{O}_{5}, 519.3105$ ).

\subsubsection{Hyperhenol (3)}

Yellow oil; $[\alpha]+199.0(c 0.31, \mathrm{MeOH}) ; \mathrm{UV}(\mathrm{MeOH}) \lambda_{\max }$ ( $\log \varepsilon$ ) 202 (4.08), 228 (3.98), 239 (3.97), 281 (3.83), 326 (3.91) nm; IR (KBr) $\nu_{\text {max }} 3431,2970,2932,2878,1651$, 1522, 1470, $1437 \mathrm{~cm}^{-1} ;{ }^{1} \mathrm{H}$ and ${ }^{13} \mathrm{C}$ NMR data, see Tables 1 and 2; ESIMS $m / z 429[\mathrm{M}-\mathrm{H}]^{-}$; HRESIMS $m / z 429.2653$ $[\mathrm{M}-\mathrm{H}]^{-}$; (calcd for $\left.\mathrm{C}_{26} \mathrm{H}_{37} \mathrm{O}_{5}, 429.2646\right)$.

\subsubsection{Hyperhenol (4)}

Yellow oil; $[\alpha]+5.3(c 0.26, \mathrm{MeOH}) ; \mathrm{UV}(\mathrm{MeOH}) \lambda_{\max }$ (log $\varepsilon) 320$ (2.14), 275 (2.30), 241 (2.42), 197 (2.50), 310 (2.17), 269 (2.30), 215 (2.34) nm; IR (KBr) $\nu_{\text {max }} 3422,2970$, 2935, 2876, 1657, 1618, 1530, 1462, $1379 \mathrm{~cm}^{-1} ;{ }^{1} \mathrm{H}$ and ${ }^{13} \mathrm{C}$ NMR data, see Tables 1 and 2; ESIMS $m / z 427[\mathrm{M}+\mathrm{H}]^{+}$; HRESIMS $m / z$ 427.2855 $[\mathrm{M}+\mathrm{H}]^{+}\left(\right.$calcd for $\mathrm{C}_{27} \mathrm{H}_{38} \mathrm{O}_{4}$, 426.2843).

\subsubsection{Hyperhenol (5)}

Yellow oil; $[\alpha]-45.0(c$ 0.12, MeOH); UV $(\mathrm{MeOH})$ $\lambda_{\text {max }}(\log \varepsilon) 354(2.40), 287(2.17), 231(2.53), 197(2.94)$, 300(2.15), 276(2.16), 228(2.53), 193(2.81) nm; IR (KBr) $\nu_{\max } 3429,2967,2926,2854,1727,1659,1622,1587$, $1512,1448 \mathrm{~cm}^{-1} ;{ }^{1} \mathrm{H}$ and ${ }^{13} \mathrm{C}$ NMR data, see Tables 1 and 2; ESIMS $m / z 501[\mathrm{M}+\mathrm{H}]^{+}$; HRESIMS $m / z 501.3008$ $[\mathrm{M}+\mathrm{H}]^{+}$(calcd for $\left.\mathrm{C}_{33} \mathrm{H}_{40} \mathrm{O}_{4}, 501.2999\right)$.

\subsubsection{X-ray Crystallographic Analysis of Hyperhenone E (8)}

$\mathrm{C}_{26} \mathrm{H}_{38} \mathrm{O}_{5}, M=430.56, a=22.6496(4) \AA, \quad b=9.4550(2)$ $\AA, c=23.8898(4) \AA, \alpha=90^{\circ}, \beta=94.6410(10)^{\circ}, \gamma=90^{\circ}$, $V=5099.27(16) \AA^{3}, T=100(2) \mathrm{K}$, space group $P 21$, $Z=8, \mu(\mathrm{CuK} \alpha)=0.609 \mathrm{~mm}^{-1}, 56,500$ reflections measured, 17,671 independent reflections $\left(\mathrm{R}_{\mathrm{int}}=0.0269\right)$. The final $R_{l}$ values were $0.0363(I>2 \sigma(I))$. The final $w R\left(F^{2}\right)$ values were $0.0966(I>2 \sigma(I))$. The final $R_{1}$ values were 0.0366 (all data). The final $w R\left(F^{2}\right)$ values were 0.0971 (all data). The goodness of fit on $F^{2}$ was 1.056 . Flack parameter $=0.02(2)$. Crystallographic data for the structure of $\mathbf{8}$ have been deposited in the Cambridge Crystallographic Data Centre (deposition number: CDCC 1,941,889).

\subsubsection{Cell Culture}

HeLa cells, GFP-LC3 HeLa cells, YFP-Parkin HeLa cells and A549 cells were maintained in DMEM (Gibco, 
D11527) supplemented with $10 \%$ fetal bovine serum, FBS (HyClone, SV30160.03) and $100 \mathrm{U} / \mathrm{mL}$ penicillin-streptomycin (Gibco/Invitrogen, 15,140-122) in a humidified atmosphere containing $5 \% \mathrm{CO}_{2}$ at $37^{\circ} \mathrm{C}$.

3.3.7.1 MTT Assay and Determination of $\mathrm{IC}_{50}$ The cells were seeded in a 96-well tissue culture plate at a predetermined density in $100 \mu \mathrm{L}$ of complete medium, attached overnight, and then treated with a series of concentrations of compound for $72 \mathrm{~h}$. At the end of the incubation period, $10 \mu \mathrm{L}$ MTT solution was added into each well of a 96-well plate for $4 \mathrm{~h}$ at $37^{\circ} \mathrm{C}$. After the medium was removed, 100 $\mu \mathrm{L}$ DMSO was added to dissolve the purple crystals. After shaking for $5 \mathrm{~min}$, the optical densities at $490 \mathrm{~nm}$ were measured using a Microplate Reader.

3.3.7.2 MitoTracker Red Staining HeLa cells were seeded on coverslips and treated with compounds $\mathbf{6}$ and $\mathbf{7}$ for $48 \mathrm{~h}$. We then removed the media from the dish and added staining solution containing MitoTracker red (100 nM) incubation $30 \mathrm{~min}$ at $37^{\circ} \mathrm{C}$. The cells were fixed with $4 \%$ PFA in PBS for 15 min and observed using a fluorescence microscope.

3.3.7.3 Flow Cytometry Analysis HeLa cells were treated with various concentrations of $\mathbf{7}$ and $\mathbf{8}$ for 48 h. Subsequently, the cells were harvested, washed with PBS and fixed with $70 \%$ alcohol at $4{ }^{\circ} \mathrm{C}$ overnight. Then cells were washed with PBS and stained with $20 \mu \mathrm{g} / \mathrm{mL}$ PI/RNase staining buffer for $30 \mathrm{~min}$ and analyzed using FACSCalibur flow cytometer (Becton Dickinson, USA).

\subsubsection{Immunofluorescence Microscopy}

The GFP-LC3 or YFP-Parkin HeLa cells were treated with compounds for the indicated time point, and then the cells were fixed with $4 \%$ PFA in PBS for $15 \mathrm{~min}$ at room temperature. The cells were observed under a fluorescence microscope (Olympus, IX83).

\subsubsection{Wound Healing Assay}

Wound healing was used to evaluate cell motility as our previous study [16]. Briefly, A549 cells were seeded into a 24-well culture plate. When the cells grew to $90 \%$ confluence, then a scratch was gently created through the cell monolayer by sterile $10 \mu \mathrm{L}$ pipette tips and loose cells were washed away. The cell migration was observed and imaged under an IX83 microscope for each condition and timepoint (0, 48 h). (Olympus, Tokyo, Japan).

\subsubsection{Cell Migration Assay}

Cell migration assay were performed as described previously [17]. In brief, cell migration was estimated using transwell chambers (Millicell, Germany) with a pore size of $8 \mu \mathrm{M}$. For the migration assay, $4.5 \times 104$ A549 cells resuspended in $100 \mu \mathrm{L}$ serum-free medium were seeded in the upper chamber with serum-containing medium in the lower chamber of 24-well transwell plates (BD Biosciences, San Jose, CA). After $24 \mathrm{~h}$, the experiment was terminated by wiping the cells from the wells with a cotton swab and fixed and stained with $0.05 \%$ crystal violet for $20 \mathrm{~min}$, scored under a light microscope in five random fields.

\subsubsection{Western Blotting Analysis}

Cells were harvested and lysed in a lysis buffer $(62.5 \mathrm{mM}$ Tris at pH 6.8, 20\% glycerol, 2\% SDS, phosphatase inhibitor), proteins were separated on SDS polyacrylamide gels and transferred to PVDF membranes (Millipore, Billerica, MA, USA). The membranes were blocked with 5\% nonfat milk, and immunoblotted with primary antibodies at $4{ }^{\circ} \mathrm{C}$ overnight. After washed three times with TBST, membranes were incubated for $1 \mathrm{~h}$ with appropriate secondary antibodies at room temperature. The follow antibodies were used in our experiments: Caspase-3 (CST, 9662), Cleaved-caspase-3 (CST, 9661), Caspase-9 (CST, 9502), PARP (CST, 9542), LC3 (Sigma, L7543), P62 (BML, PM045), PINK1 (CST, 6946), Tim23 (BD, 611222), Tom 20 (sc-17764), E-cadherin (CST, 3195), Vimentin (CST, 5741), pAKT (Ser473, CST, 9171), AKT (CST, 9272), Cofilin (CST, 5175) and GAPDH (CST, 5174). GAPDH was used as the loading control. Membranes were visualized with Image Quant LAS 4000 (General Electric Company).

Acknowledgements The work was financially supported by the NSFC-Joint Foundation of Yunnan Province (U1902213), Chongqing Municipal Natural Science Foundation (cstc2018jcyjAX0388), the Second Tibetan Plateau Scientific Expedition and Research (STEP) program (2019QZKK0502), Southeast Asia Biodiversity Research Institute, CAS (2017CASSEABRIQG003), State Key Laboratory of Phytochemistry and Plant Resources in West China (P2017-KF02 and P2019-ZZ05), and the Natural Sciences Foundation of Yunnan Province (2019FA003).

\section{Compliance with Ethical Standards}

Conflict of interest All authors declare no conflict of interest.

Open Access This article is licensed under a Creative Commons Attribution 4.0 International License, which permits use, sharing, adaptation, distribution and reproduction in any medium or format, as long as you give appropriate credit to the original author(s) and the source, provide a link to the Creative Commons licence, and indicate if changes were made. The images or other third party material in this article are included in the article's Creative Commons licence, unless indicated 
otherwise in a credit line to the material. If material is not included in the article's Creative Commons licence and your intended use is not permitted by statutory regulation or exceeds the permitted use, you will need to obtain permission directly from the copyright holder. To view a copy of this licence, visit http://creativecommons.org/licenses/by/4.0/.

\section{References}

1. I.P. Singh, S.B. Bharate, Nat. Prod. Rep. 23, 558-591 (2006)

2. R. Ciochina, R.B. Grossman, Chem. Rev. 106, 3963-3986 (2006)

3. X.W. Yang, R.B. Grossman, G. Xu, Chem. Rev. 118, 3508-3558 (2018)

4. S.B. Wu, C. Long, E.J. Kennelly, Nat. Prod. Rep. 31, 1158-1174 (2014)

5. J. Barnes, L.A. Anderson, J.D. Phillipson, J. Pharm. Pharmacol. 53, 583-600 (2001)

6. Y. Liao, X. Liu, J. Yang, Y.Z. Lao, X.W. Yang, X.N. Li, J.J. Zhang, Z.J. Ding, H.X. Xu, G. Xu, Org. Lett. 17, 1172-1175 (2015)
7. J.J. Zhang, J. Yang, Y. Liao, X.W. Yang, J.Z. Ma, Q.L. Xiao, L.X. Yang, G. Xu, Org. Lett. 16, 4912-4915 (2014)

8. M. Nagai, M. Tada, Chem. Lett. 16, 1337-1340 (1987)

9. M. Lan, in South Yunnan Materia Medica, ed. by Z.Y. Wu, L. Gao (Science Press, Kunming, 2008), pp. 236-240

10. X.W. Yang, Y. Ding, J.J. Zhang, X. Liu, L.X. Yang, X.N. Li, D. Ferreira, L.A. Walker, G. Xu, Org. Lett. 16, 2434-2437 (2014)

11. Y. Liao, S.Y. Yang, X.N. Li, X.W. Yang, G. Xu, Sci. China 59, 1216-1223 (2016)

12. J.J. Zhang, X.W. Yang, J.Z. Ma, Y. Ye, X.L. Shen, G. Xu, Tetrahedron 71, 8315-8319 (2015)

13. X.W. Yang, M.M. Li, X. Liu, D. Ferreira, Y. Ding, J.J. Zhang, Y. Liao, H.B. Qin, G. Xu, J. Nat. Prod. 78, 885-895 (2015)

14. J.Q. Cao, X.J. Huang, Y.T. Li, Y. Wang, L. Wang, R.W. Jiang, W.C. Ye, Org. Lett. 18, 120-123 (2016)

15. P. Jiang, N. Mizushima, Cell. Res. 24, 69-79 (2014)

16. X. Wang, Y. Lao, N. Xu, Z. Xi, M. Wu, H. Wang, X. Li, H. Tan, M. Sun, H. Xu, Sci. Rep. 5, 10293 (2015)

17. J. Zhang, Z. Zheng, M. Wu, L. Zhang, J. Wang, W. Fu, N. Xu, Z. Zhao, Y. Lao, H. Xu, Cell Death Dis. 10, 554 (2019) 